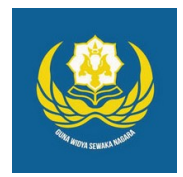

Jurnal Analogi Hukum

Journal Homepage: https://ejournal.warmadewa.ac.id/index.php/analogihukum

\title{
Pemberatan Hukuman Terhadap Residivis (Studi Kasus Putusan Perkara Nomor 50/Pid.B/2018/PN.Tab)
}

\author{
Ni Made Wahyuni Paramitha*, I Ketut Sukadana dan Ni Made Sukaryati Karma \\ Universitas Warmadewa, Denpasar-Bali, Indonesia \\ *wahyuniparamitha@gmail.com
}

How To Cite:

Paramitha, N. M. W., Sukadana, I. K., \& Karma, N. M. S. (2021). Pemberatan Hukuman Terhadap Residivis (Studi Kasus Putusan Perkara Nomor 50/Pid.B/2018/PN.Tab). Jurnal Analogi Hukum. 3(1). 84-89. Doi: https://doi.org/10.22225/ah.3.1.3020.84-89

\begin{abstract}
With existence of law expected by state Indonesia become peaceful state and can prevent the happening of crime. Its function criminal law arrange life of society to be can create orderliness of public. These time often met by various crime case conducted by recidivist, where the recidivist don't discourage to penalization which he have against the punismentin prison previously. Research problems of this study are (1) How arrangement of law to recidivist according to positive law in Indonesia? (2) How base consideration of judge in breaking a recidivist? This research use approach of normatif that is with method approach of legislation, conceptual, and approach of case. Result indicate that: (1) Arrangement of law to recidivist according to Indonesian positive law is pursuant to section 486 Criminal code which enter in certain type of crimes, in section 486 Criminal code arrange about maximum crime from some criminal of which can added by $1 / 3$ one-third because conducting repetition of or deed of recidive. (2) Base consideration of judge in breaking a recidivist that is in the balance punish Assembly Judge of Tabanan constitution its decision regarding have proven of validly and assure mistake of defendant of Section assertion 362 Criminal code have precisely and correctness. But regarding dropped crime penalization to defendant according to writer don't in agreement with the decision because of existence of dimness of norm and also not yet fulfilled sense of justice and rule of law which where judge ought to add 1/3 one-third from maximum crime threat of fundamental because defendant a recidivist.
\end{abstract}

Keywords: Case Verdict Number 50/Pid.B/2018/PN.Tab; Recidivist; Weighting On Punishment

\begin{abstract}
Abstrak - Dengan adanya hukum diharapkan Negara Indonesia menjadi negara yang aman dan dapat mencegah terjadinya kejahatan. Hukum pidana berfungsi dalam mengatur kehidupan masyarakat agar dapat menciptakan ketertiban bagi banyak orang. Saat ini banyak dijumpai berbagai kasus kejahatan yang dilakukan oleh residivis, dimana residivis tersebut tidak jera terhadap hukuman yang pernah ia jalani sebelumnya dipenjara. Rumusan masalah penelitian ini adalah (1) Bagaimanakah pengaturan hukum terhadap residivis menurut hukum positif di Indonesia? (2) Bagaimanakah dasar pertimbangan hakim dalam memutus seorang residivis? Penelitian ini menggunakan pendekatan normatif yaitu dengan metode pendekatan perundangundangan, konseptual, dan pendekatan kasus. Hasil menunjukkan bahwa: (1) Pengaturan hukum terhadap residivis menurut hukum positif Indonesia ialah didasarkan pada pasal 486 KUHP yang termasuk dalam kelompok jenis kejahatan-kejahatan tertentu, dalam pasal 486 KUHP mengatur menegnai pidana maksimum dari beberapa kejahatan yang dapat ditambah 1/3 sepertiga karena melakukan pengulangan perbuatan atau recidive. (2) Dasar pertimbangan hakim dalam memutus seorang residivis yaitu dalam pertimbangan hukum Majelis Hakim Pengadilan Negeri Tabanan yang mendasari putusannya mengenai telah terbuktinya secara sah dan meyakinkan kesalahan terdakwa atas dakwaan Pasal 362 KUHP telah tepat dan benar. Namun mengenai hukuman pidana yang dijatuhkan kepada terdakwa menurut penulis tidak sependapat dengan putusan tersebut dikarenakan adanya kekaburan norma serta belum memenuhi rasa keadilan dan kepastian hukum yang dimana hakim seharusnya menambah $1 / 3$ sepertiga dari ancaman pidana maksimum pokok karena terdakwa adalah seorang residivis.
\end{abstract}

Kata Kunci: Putusan Perkara Nomor 50/Pid.B/2018/PN.Tab; Residivis; Pemberatan Hukuman

Jurnal Analogi Hukum, Volume 3, Nomor 1, 2021. CC-BY-SA 4.o License 


\section{Pendahuluan}

Indonesia yakni negara kepulauan yang terdiri atas berbagai macam suku, agama dan adat istiadat yang berbeda satu sama lainnya, sejak di proklamasikan kemerdekaannya, negara kita ini terbentuk menjadi negara kesatuan dengan satu sistem hukum, yang mana sistem hukum ini diharapkan mampu sebagai penegak keadilan dan ketertiban bangsa negara serta mencegah terjadinya kejahatan. Hukum merupakan hal yang tertinggi dalam mengatur kehidupan di masyarakat maka dari itu Indonesia di sebut sebagai Negara Hukum, ini tetuang pada Pasal 1 ayat 3 UUD 1945 yang menyatakan bahwa Indonesia adalah Negara Hukum.

Sistem hukum yang berkaku di Indonesia saat ini adalah sistem hukum eropa kontinental, bukti adanya sistem hukum ini adalah KUHP yang saat ini dianggap masih berlaku. Pada dasarnya semua hukum memiliki tujuan dalam menciptakan suatu ketertiban dan kepastian hukum, hukum pidana berperan didalam mengatur kehidupan bermasyarakat supaya dapat menciptakan dan memelihara ketertiban umum. Hal ini di dasarkan pada banyaknya kepentingan dan kebutuhan diantara manusia yang berbeda satu sama lainnya dan saling bertentangan. Usaha dan kebijakan untuk membuat peratuan hukum pidana yang baik tidak terlepas dari tujuan hukum sebagai penanggulangan kejahatan, dimana penanggulagan kejahatan melalui pembuatan UU (hukum) pidana pada hakikatnya juga merupakan bagian integral dari usaha perlindungan masyarakat (Arief, 2014).

Penyelesaian perkara pidana diselesaikan secara konvensional melalui sebuah badan yang disebut dengan pengadilan. Berdasarkan Pasal 4 ayat (2) UU No 48 Tahun 2009 tentang Kekuasaan Kehakiman menyebutkan bahwa pengadilan mebantu pencari keadilan dalam mengatasi segala persoalan hukum khususnya demi terciptaknya peradilan yang sederhana, cepat dan biaya ringan (Sutiyoso \& Puspitasari, 2005). Dengan demikian penggunaan hukum pidana dalam rangka kebijakan kriminal haruslah di pandang sebagai salah satu usaha masyarakat dalam rangka penanggulangan kejahatan, penggunan sanksi pidana merupakan salah satu segi disamping upaya mempengaruhi masyarakat tertang kejahatan dan pemidanaan dan pencegahan tanpa mengenakan pidana dengan menempuh jalur perdata maupun administrasi. Untuk melihat efektivitas sanksi (pidana) lebih dahulu dikemukakan tentang sistem sosial, sistem hukum, sistem pengendalian sosial, dan sistem penegakkan hukum. Steven Vago mengemukakan bahwa pengendalian sosial menggunaan sarana hukum terjadi apabila bentuk bentuk pengendalian sosial lain tidak efektif, pengendalian sosial merupakan hasil dari usaha sosialisasi melalui proses belajar yang dikembangkan oleh kelompok individu.

Penggunaan hukum sebagai sarana pengendalian sosial terlalu sederhana dibandingkan dengan kompleksitas yang dihadapi oleh masyarakat termasuk juga penggunaan hukum pidana. Dalam rangka penggunaan hukum pidana sebagai sarana pppenanggulangan kejahatan perlu dipertimbangkan faktor keseimbangannya antara lain :

- Keseimbangan merupakan sarana yang dapat dipergunakan dalam hubungannya terhadap hasil-hasil yang ingin dicapai.

- Analisa biaya terhadap hasil yang akan diperoleh dalam hubungannya untuk mencapai tujuan yang diinginkan

- Penilaian atau penafsiran tujuan yang dicapai

- Pengaruh sosial terhadap kriminalisasi dan diskriminalisasi

Saat ini sering dijumpai berbagai kasus yang dilakukan oleh residivis, hal ini terjadi tatkala seorang yang tidak jera terhadap hukuman yang pernah ia jalani sebelumnya di penjara, setelah ia bebas dari hukuman ia melakukan pengulangan tindak pidana lagi di masyarakat dan menimbulkan keresahan bagi masyarakat. Dalam kasus ini membahas mengenai hukuman pemberatan terhadap residivis, dimana seorang pelaku tindak pidana yang pernah dihukum sebelumnya seharusnya jera terhadap perbuatannya mengingat bahwa ia pernah menjalani hukuman dan kebebasannya di batasi. Donald Cleamer menyatakan bhawa semakin lama pidana dijatuhkan pada seorang narapidana maka orang tersebut cenderung menjadi terprisonisasi, sesungguhnya seorang narapidana yang tinggal secara bersama dalam waktu yang lama cenderung membentuk suatu masyarakat tersendiri dengan segala macam konsekuensinya.

Prisonisasi yakni suatu proses penyerapan bagaimana cara kehidupan di dalam lembaga pemasyarakatan, penyerapan ini dilakukan dengan cara belajar dan berinteraksi dengan sesama narapidana, besar kecilnya pengaruh kehidupan narapidana dari moral dan kebiasaan yang dilakukan di dalam lembaga 
pemasyarakatan ini dapat merubah perilaku narapidana oleh karena itu kemungkinan untuk melakukan pelanggaran lagi setelah keluar dari penjara. Prisonisasi memberikan dampak negatif khusunya bagi terpidana yang dijatuhi hukuman pidana penjara karena melakukan tindak pidana baru pertama kali. Hal inilah yang menyebabkan seorang narapidana melakukan pengulangan tindak pidana (residiv) di dalam kehidupan masyarakat karena dampak negatif yang di dapat selama menjalani hukuman di lembaga pemasyarakatan.

Pada penelitian sebelumnya dengan judul penelitian Pemberatan Hukuman terhadap Residivis dalam KUHP Ditinjau menurut Hukum Islam, (Usman \& Zikru, 2017) mengungkapkan Bahwa seorang pelaku tindak pidana harus dijatuhi hukuman yang telah ditetapkan untuk tindak pidana tersebut, tetapi jika pelaku kembali mengulangi tindak pidana yang pernah dilakukannya, maka hukuman yang akan dijatuhkan kepadanya dapat diperberat. Berdasarkan latar belakang tersebut diatas, melihat bahwa hukuman yang yang dijatuhi pada seorang narapida khususnya seorang residivis tidak dapat memberikan efek jera, maka penulis encoba meneliti dan membahas lebih jauh lagi maslah tersebut dalam bentuk karya ilmiah (skripsi) dengan judul "Pemberatan Hukuman Terhadap Residivis (Studi Kasus Putusan Perkara Nomor 50/Pid.B/2018/PN.Tab)"

Berdasarkan latar belakang masalah tersebut diatas, maka dapat dirumuskan permasalahan sebagai berikut:

- Bagaimana pengaruh hukum terhadap residivis menurut hukum positif di Indonesia?

- Bagaimana dasar pertimbangan hakim dalam memutus seorang residivis?

Penelitian ini bertujuan untuk :

- Untuk mengatahui dan mnegkaji tentang hukuman terhadap residivis menurut hukum positif di Indonesia.

- Untuk mengetahui dan mengkaji dasar pertimbangan putusan hakim dalam memutus seorang residivis.

\section{Metode}

Jenis penelitian yang digunakan dalam penelitian ini adalah jenis penelitian hukum normatif yaitu dengan melakukan pengkajiannya berdasarkan bahan-bahan hukum dari literatur dan merupakan suatu proses untuk menemukan aturan hukum, prinsip hukum, konsep hukum guna menyelesaikan masalah yang dihadapi. Sedangkan pendekatan masalah yang digunakan secara yuridis yaitu dengan meninjau peratiuran yang berhubungan dengan permasalahan.

Sumber bahan hukum dalam penelitian ini adalah:

- Bahan hukum Primer, yaitu: bahan hukum yang berpusat peraturan UU yang berlaku di Indonesia: UUD RI Tahun 1945, UU RI No 1 Tahun 1942 tentang KUHP

- Bahan Hukum Sekunder yaitu: bahan-bahan hukum yang diperoleh dari pengkajian kepustakaan (Library Research), seperti: buku, jurnal-jurnal hukum, surat kabar, internet, dan pendapat para ahli. Serta Putusan No.50/Pid.B/2018/PN.Tab, dimana bahan hukum tersebut akan ditulis hasil wawancara dengan informn yaitu hakim di Pengadilan Negeri Tabanan.

\section{Hasil dan Pembahasan}

\section{Pengaturan Hukum Terhadap Residvis Menurut Hukum Positif Indonesia}

Recidive ialah pengulangan dari suatu tindak pidana yang dilakukan oleh pelaku yang sama dari tindak pidana sebelumnya yang telah dijatuhi hukuman dan inkrah, serta pengulangan yang terjadi dalam jangka waktu tertentu, adapun syarat yang harus dipenuhi dalam hal pengulangan tindak pidana (recidive) (Farid, 2010):

- Merupakan pelaku yang sama

- Kembalinya tindak pidana terdahulu yang sudah dijatuhi pidana dan mempunyai kekuatan hukum tetap.

- Pengulangan dalam jangka waktu tertentu

Dilihat dari jenis tindak pidana yang pernah diulangi:

- Pengulangan Umum merupakan pengulangan dati tindak-pidana.

- Pengulangan khusus ialah tindak pidana yang serupa dan dilakukan kembali.

- Orang tersebut sudah menjalani seluruh atau sebagian pidana yang diputuskan oleh hakim

- Melakukan pengulangan tindak pidana dalam jangka waktu tidak boleh melebih dari 5 tahun sejak terpidana menjalani sebagian 
atau seluruh pidana yang diputus.

Sebagaimana ketentuan pasal 65 KUHP terkait tenggang waktu hapusnya kewenangan negara dalam menjalankan pidana, yaitu:

- 2 tahun lamanya untuk semua pelanggaran

- 5 Tahun untuk kejahatan yang dilakukan dengan menggunakan sarana percetakan

- Mengenai kejahatan lainnya, yakni ada 3 kategori :

a) Pidana yang dijatuhkan terhadap kejahatan dikenakan Pidana denda , pidana kurungan dan pidana penjara.

b) Pidana yang dijatuhkan terhadap kejahatan diancam dengan pidana penjara selama 3 tahun yaitu setelah 16 tahun (12 tahun ditambah dengan 1/3)

c) Pidana mati atau pidana seumur hidup mengenai kejahatan yaitu setelah 24 tahun (18 tahun ditambah 1/3)

Kejahatan dikelompokkan dalam pasal 486, 487, dan 488 KUHP dapt dilihat dari pengulangan perbuatannya berdasarkan kepada kepentingan hukum yang dilanggar, selain itu juga dapat dibedakan berdasrkan jenis dari pengulangan umum dan pengulangan khusus, dalam doktrin hukum pidana sama artinya dengan bentuk pengulangan kebetulan (accidentally recidive) dan pengulangan kebiasaan (habitual reddive). Pengulangan kebetulan yakni pelaku didalam melakukan tindakan pidana yang diulangi disebabkan oleh hal-hal yang bukan berasal dari faktor sifat atau wataknya yang buruk, melainkan oleh faktor yang memang tidak dapat diatasinya sendiri. Berbeda dengan pengulangan yang dikarenakan oleh kebiasaan, yang menunjukkan wataknya yang buruk. Beberapa narapidana yang telah bebas dari LP tidak menjadikan wataknya menjadi lebih baik, tetapi adanya pengaruh pergaulan di dalam LP menambah sifat buruknya, dan mengakibatkan untuk berbuat tindak pidana lagi.

Sejauh ini peraturan hukum dan perundang -undangan belum mengatur secara khusus tentang pengulangan kejahatan atau (residive), hanya diatur secara terbatas di dalam KUHP.

KUHP tidak mengatur secara jelas mengenai pengertian dari pengulangan kejahatan (residive), namun hanya beberapa pasal saja yang mengatu mengenai pemberatan terhadap narapidana yang melakukan pengulangan kejahatan tersebut. Dari sudut hukum pidana, pengulangan tindak pidana dibedakan menjadi 3 jenis, yakni (Chazawi, 2002):

- Pengulangan tindak pidana yang dibedakan atas cakupannya, yakni :

a) Dalam artian yang lebih luas apabila seseorang melakukan suatu perbuatan kejahatan tanpa disertai oleh suatu penjatuhan hukuman yang inkrah.

b) Dalam artian lebih sempit bilamana si pelaku telah melakukan kejahatan yang sama dan telah menjalani masa hukuman tertentu dan mengulangnya lagi perbuatan yang sama tersebut dalam waktu tertentu, Misalnya 5 tahun dari terpidana menjalani $1 / 2$ dari hukuman yang telah dijatuhkan.

- Pengulangan tindak pidana yang dibedakan berdasarkan sifatnya antara lain :

Accidentale recidive merupakan pengulangan tindak pidana yang dilaksanakan berdasarkan keadaan yang memaksa dan mendesak hal itu disebut pengulangan perbuatan kejahatan dilaksanakan atas yang sudah direncanakan atau disebut Habituele recidive.

Selain 2 bentuk diatas, pengulangan tindak pidana juga dibedakan atas, Residivis Umum yakni apabila orang yang telah melakukan kejahatan yang telah dijatuhi hukuman dan kemudian dia melaksanakan tindak pidana lagi dan Residive khusus yaitu apabila seseorang melakukan kejahatan yang sudah dijatui hukuman, dan kemudian ia melakukan kejahatan pidana yang sama atau sejenis.

Adapun persyaratan recidive menurut ketentuan pasal tersebut adalah sebagai berikut :

Kejahatan yang diulang harus termasuk dalam suatu kelompok jenis dengn kejahatan yang pertama atau yang terdahulu, jenis kejahatan yang dimaksud adalah :

- Berbagai macam jenis pidana didalam pasal 486 KUHP, Hal ini dijadikan dasar untuk memperberat pidana dengan $1 / 3$ nya dari syarat kejahatan dimana dilakukan harus sudah dipidana oleh putusan hakim yang tidak dapat dirubah lagi.

- Golongan/ macam-macam kejahatan pada pasal 487 KUHP, kebanyakan penyerangan ataupun makar kepada kepala Negara.

- Golongan/macam-macam kejahatan pada pasal 488 KUHP yakni kebanyakan perbuatan penghinaan dimana pada 
percetakan / penerbitan (Widnyanya, 2010).

Sehingga dengan demikian menurut penulis setelah selesai menjalani hukumannya dan dalam jangka waktu tertentu yang telah ditetapkan undang-undang, jika orang tersebut melakukan tindak pidana lagi, maka pemidanaanya dilakukan berdasarkan golongan dalam pasal-pasal tertentu yaitu dalam pasal 486, Pasal 487, dan pasal 488 KUHP terhadap penambahan pidananya.

\section{Dasar Pertimbangan Hakim dalam Memutus Seorang Residivis}

Menurut Andy Sofyan, majelis hakim dalam memutus suatu perkara dalam hal ini memberikan 2 pertimbngan yaitu :

\section{- Pertimbngan Yuridis}

a) Yang menjadi pemberatan dalam Pidana

UU yang membedakan antara pembedaan pemberatan pidana umum dan pembedaan pemberatan pidana khusus. Kategori yang dapat dikatakan pemberatan pidana umum, yakni :

a) Dasar Pemberatan berdasarkan jabatan.

b) Dasar pemberatan pada Pasal 52 huruf (a) KUHP

Dasar pemberatan pidana dikarenakan pengulangan (recidive), tidak dipandang dalam pengulangan tindak pidana, yakni berkenaan dengan syarat tertentu pada UU.

\section{- Pertimbangan Sosiologis}

Faktor-faktor yang harus diperhatikan dalam menjatuhkan pidana adalah wajib dipertimbangkan Kesalahan terdakwa, motif, dan tujuan serta cara melakukannya, sikap batin si pembuat tindak pidana, riwayat hidup dan keadaan sosial ekonominya, sikap dan tindakan pembuat setelah mendapatkan hukuman, Pengaruh pidana terhadap masa depannya, Pandangan masyarakat terhadap tindak pidana, Pengurus tindak pidana terhadap korban atau keluarga korban, Apakah tindak pidana dilakukan dengan berencana (Widnyanya, 2010).

Seperti kasus yang melatarbelakangi Putusan Pengadilan No.50/Pid.B/2028/PN.Tab, dimana terdakwa I Putu Gede Sudarsana melakukan Tindak Pidana pencurian kendaraan bermotor di Desa Kukuh, Kecamatan marga, Kabupaten Tabanan yang merupakan wilayah hukum PN. Tabanan, dimana terdakwa sebelumnya telah melakukan tindak pidana yang sama, dan ini sudah memenuhi unsur dari pengulangan tindak kejahatan (residive), dengan tujuan untuk memiliki secara melawan hukum pada pasal 362 KUHP, dengan mempertimbangkan hal-hal yang memberatkan dan meringankan terdakwa, maka majelis memutus menjatuhkan pidana terhadap terdakwa dengan pidana penjara selama 2 tahun. Terhadap putusan tersebut penulis tidak sependapat dengan majelis hakim karena berdasarkan ketentuan pasal 486 KUHP sudah jelas bahwa tentang pidana maksimum daapat di tambah sepertiga karena residive, sehingga majelis hakim septutnya memutus menjatuhkan hukuman pada terdakwa ditambah sepertiga dari ancaman maksimum pidana penjara, karena orang itu terbukti memiliki tabiat yang jahat dan mengulangi tindak pidana yang terdahulu dimana ia sudah sempat dijatuhi hukuman.

\section{Simpulan}

Dasar pertimbangan hakim dalam memutus seorang residivis yaitu telah terpenuhinya unsur-unsur yang tercantum pada pasal 362 KUHP, namun penulis tidak sependapat terhadap putusan tersebut karena adanya kekaburan norma yang bagi penulis belum memberikan rasa keadilan dan kepastian hukum, serta efek jera bagi terdakwa dan tindak menutup kemungkinan akan terulang lagi hal yang sama , karena seharusnya majelis menambah hukuman sepetiga dari ancaman pidana maksimum kepada terdakwa mengingat bahwa terdakwa adalah seorang residivis. Berdasarkan pasal 486 KUHP yang masuk dalam kelompok jenis kejahatan-kejahatan tertentu. Kelompok jenis kejahatan dalam pasal 486 KUHP yaitu mengenai kejahatan terhadap harta benda dan pemalsuan yang diantaranya pencurian sebagaimana diatur dalam Pasal 362, 363, 365 KUHP. Sehingga dengan demikian dalam pasal 486 KUHP mengatur tentang pidana maksimum dari beberapa kejahatan yang dapat ditambah 1/3 sepertiga karena melakukan pengulangan perbuatan atau recidive.

Dasar pertimbangan hakim dalam memutus seorang residivis yaitu dalam pertimbangan hukum Majelis Hakim Pengadilan Negeri Tabanan No.50/Pid.B/2018/ PN.Tab yang mendasari putusannya mengenai telah terbuktinya secara sah dan meyakinkan kesalahan terdakwa atas dakwaan Pasal 362 KUHP telah tepat dan benar. Namun mengenai hukuman pidana yang dijatuhkan kepada terdakwa I Putu Gede Sudarsana menurut penulis tidak sependapat dengan putusan tersebut dikarenakan adanya kekaburan norma serta belum memenuhi rasa keadilan dan kepastian hukum yang dimana hakim 
seharusnya menambah $1 / 3$ sepertiga dari ancaman pidana maksimum pokok karena terdakwa adalah seorang residivis.

Untuk dapat menangulangi pengulangan kejahatan (residive) penegak hukum harus melakukan penindakan secara tegas terhadap pelaku agar memberikan efek jera (deterrent effect) dan daya cegah (preveny effect) sebagai upaya pencegah tindak pidana yang ada dalam masyarakat dan diharapkan kepada para hakim agar lebih jeli dalam memperhatikan pertimbangan hukum secara filosofis, sosisologis, serta yuridis, untuk menegakkan suatu keadilan hukum sehingga penegakan hukum di Indonesia berjalan sesuia dengan koridor dan ketentuan-ketentuan hukum yang berlaku.

Diharapkan kepada para hakim agar lebih jeli memperhatikan pertimbangan hukum secara filosofis, sosiologis, serta yuridis, untuk menghindari adanya ketidakpastian, keadilan, dan kemanfaatan dalam memutus sebuah perkara khususnya tindak pidana pencurian yang dilakukan oleh seorang residivis. Sehingga dengan demikian penegakan hukum di Indonesia berjalan sesuai dengan koridor dan ketentuan-ketentuan yang berlaku.

\section{Daftar Pustaka}

Arief, B. N. (2014). Bunga Rampai Kebijakan Hukum Pidana (Perkembangan Penyusunan Konsep KUHP baru). Jakarta: Kencana Prenada Media Group.

Chazawi, A. (2002). Pelajaran Hukum Pidana Bagian II. Jakarta: PT Raja Grafindo Persada.

Farid, Z. A. (2010). Hukum Pidana I. Jakarta: Sinar Grafika.

Sutiyoso, B., \& Puspitasari, S. H. (2005). Aspek -Aspek Perkembangan Kekuasaan Kehakiman Di Indonesia. Yogyakarta: Universitas Islam Indonesia Press.

Usman, S., \& Zikru, M. (2017). Pemberatan Hukuman terhadap Residivis dalam KUHP Ditinjau menurut Hukum Islam. Legitimasi: Jurnal Hukum Pidana Dan Politik Hukum, 6(1). Retrieved from http://dx.doi.org/10.22373/

legitimasi.v6i1.1843

Widnyanya, I. M. (2010). Asas-Asas Hukum Pidana. Jakarta: Fikahati Aneska. 